\title{
Spatial Differentiation of the Standard of Living in the Population as a Representation of Disproportions in Socioeconomic Development: A Case Study of Belgorod Oblast
}

\author{
N. V. Chugunova ${ }^{a, *}$ and N. V. Likhnevskaya ${ }^{a}$ \\ ${ }^{a}$ Belgorod National Research University, Belgorod, 308015 Russia \\ *e-mail: Chugunova@bsu.edu.ru \\ Received February 25, 2019; revised February 25, 2019; accepted April 4, 2019
}

\begin{abstract}
The article considers spatial differences in the standard of living in the population on a regional scale within Belgorod oblast; along with other regions, this federal subject is exposed to federal reforms being implemented in the socioeconomic sphere. The study determines approaches to analyzing the standard of living (SOL) and establishes its main measures. Intraregional differentiation of the SOL components is investigated, extensively using GIS technologies. The component-based study has revealed that the extent of disproportions among municipalities is particularly large for social and socioeconomic indicators, representing a decline in the number of enterprises in the social sphere and the number of employed persons in countryside. Agroholdings were found to play a significant role in the change in SOL indicators and settlement pattern of the rural population. The outcome of the research is a typology of municipal and urban districts according to their level of socioeconomic development based on the synthetic SOL measure, which has brought to light extensive intraregional disproportions. It has been determined that the high level of development is specific to the regional center (Belgorod) alone.
\end{abstract}

Keywords: standard of living, municipal units, measures, socioeconomic development, differentiation

DOI: $10.1134 / \mathrm{S} 2079970519030031$

\section{FORMULATION OF THE PROBLEM}

The Russian socioeconomic realm has accrued multiple problems and contradictions that impede the formation and building of a social state, i.e., a democratic society, where a human being is declared a supreme value (Constitution of the Russian Federation) and which creates conditions for ensuring a decent life in line with the standards of a modern developed state.

The level and conditions of living, as well as the level of socioeconomic development, considerably differ across the districts of federal subjects. Regional mechanisms of socioeconomic development administration in municipalities do not take into account local contexts of the encountered differences. It is vital that we find new forms and methods for evaluating differences between municipal units in a level of socioeconomic development and living conditions of their population. A standard of living indicator in the population can be employed for the evaluation.

Researchers across the globe and UN Population Commission are engaged in search for measures for the standard of living (SOL) in the population. Economic indicators were primarily used to assess living conditions in the population before the mid-20th cen- tury. In 1961, for the first time, a UN working party created principles to define and measure the SOL on a global scale with the use of other indicators. They were reported in a monograph by Swedish scholars, who proposed to measure SOL based on nine major components, including social, economic, and environmental indicators [13].

When analyzed, scholarly publications that look into SOL both in Russia and abroad reveal complications in establishing an approach to the SOL category: measurement can be performed based on any of the following indicators used as a principal-production development level, consumption, income, cost of living, and consumer norms and standards. A complex multiaspect approach is exceedingly rare. As a primary approach to measure and subsequently analyze SOL, Russian and international organization projects measure consumption level [5] and a set of consumption characteristics [8]. However, in the opinion of foreign experts, this approach has the substantial limitation of failing to fully account for the scale of the shadow economy [27].

Many Russian researchers acknowledge the priority of an approach that takes into account the level of consumption. Leading SOL research specialist N.M. Rimashevskaya emphasized that this category 
encapsulates actual (realistic) conditions and characteristics of the population in the sphere of consumption [18]. When measuring SOL, a number of researchers proceed from the achieved level of income and consumption of tangible goods and services [10] but consider the method to have one essential flaw: it does not allow for a human capabilities factor without elaborating on what these capabilities are.

The authors of [8] argue that the level and structure of consumption should be direct and proximate indicators of SOL, but stress that a complex integrating approach is necessary to define this concept. They presume that "the standard of living should be regarded as the level of satisfaction of people that material and intellectual necessities have attained owing to the produced economic and material conditions and possibilities realized through consumption and primarily determined by the ratio of income level to cost of living" [8, p. 19]. We believe that the formulation is missing (though not entirely) a social component, while the proposed approach underrates SOL as a socioeconomic category. When viewed as as an endpoint indicator in measuring the level of socioeconomic development in a region, SOL in essence can be more strictly defined as "levels of welfare and consumption of goods and services by the population and the set of conditions and indicators characterizing the degree to which basic needs are satisfied" [22, p. 9].

An overview of SOL measurement methodology reveals that it still needs to be improved and an aggregate indicator has yet to be found. We believe that an approach to SOL as a socioeconomic category and to its measures should be comprehensive, multiaspect, and take into account the place-based community of people at the regional or municipal level, rather than at the level of an individual. Therefore, SOL is herewith meant to cover the entire set of living conditions, labor, and daily life in a particular living environment, as well as the degree to which various necessities, including physical, economic, social, and intellectual, have been satisfied in the population of this community. Living conditions manifest themselves in a particular regional socioeconomic situation; therefore, cumulatively, evaluations should include demographic, social, socioeconomic, economic, and environmental indicators based on official statistics (imperfect as they may be).

Five big indicators are generally attributed to SOL by the Federal State Statistics Service (Rosstat) and its local subdivisions: consumption by a household, income of the population, expenses, savings and property, and housing conditions, which provide no more than an overall perspective of the way people live across Russia in its federal subjects. The available system of indicators is far from perfect, is incomplete, and unfortunately raises doubts to the plausibility of indicators, specifically ones that measure income. Thus, center stage in the section Cash Income of the
Population is taken by the indicator "Average monthly nominal gross wages (earnings)." Average wages can be misleading, whereas median earnings, which is not employed by Rosstat, results in a more accurate picture. Russia is the only state among large economies where the Federal State Statistics Service does not publish data on tax payment amounts collected from different population groups. Based on independent assessments, half the national wealth is owned by $10 \%$ of the richest citizens, who contribute as little as $5-8 \%$ of the total tax amount [7]. Nevertheless, the use of official statistics serves to avoid subjective errors and bias in SOL measurements, as well as to harmonize indicators in the comparative analysis of municipal units and regions.

The subject of our inquiry is Belgorod oblast with a population of $1.6 \mathrm{mln}$; the municipal structure includes 19 municipal districts (raions), three urban districts (okrugs), and 25 urban and 264 rural settlements.

In the Russian Federation, Belgorod oblast is an economically developed region ranked 15 th in socioeconomic status rating among federal subjects conducted by Credinform [19]. When analyzed, the results obtained by the company revealed that among the 18 measures, two are demographic and the remaining are economic, while social indicators have not been represented at all. Without due regard to the social sphere, an approach to assessing socioeconomic development level is one-sided, since SOL may be relatively low even when the level of economic indicators is high [21]. In addition, overall assessment obscures disparities between municipalities.

The main objectives of the study are to establish an approach to evaluating SOL and its measures, identify intraregional differentiation of SOL characteristics, and determine disproportions in the levels of socioeconomic development between municipalities of Belgorod oblast.

\section{RESEARCH METHODOLOGY AND TECHNIQUES}

Official statistics materials were used for the information base. The analysis was performed using a comprehensive integral approach to SOL that employs comparative geography and statistical methods, as well as GIS mapping. For the primary factor in SOL differentiation, we took the degree of socioeconomic development in society, which manifests itself through the demographic, social, and socioeconomic indicators and living conditions (environment) of the population.

To measure the SOL and socioeconomic development of Belgorod oblast, we employed techniques [4, $8,13,22]$ and proposals for improving SOL measurement [17], which allowed for aggregation of baseline data (standardized relative to the mean value) and 
Table 1

\begin{tabular}{|c|c|}
\hline Block of indicators & Indicator \\
\hline $\begin{array}{l}R_{1} \\
\text { Demographics }\end{array}$ & $\begin{array}{l}\text { 1. Birth rate, per } 1000 \text { people } \\
\text { 2. Mortality rate, per } 1000 \text { people } \\
\text { 3. Migration increase }(+) \text {, decrease }(-) \text {, per } 1000 \text { people } \\
\text { 4. Population density, persons } / \mathrm{km}^{2} \\
\text { 5. Dependency ratio, } \%\end{array}$ \\
\hline $\begin{array}{l}R_{2} \\
\text { Social conditions }\end{array}$ & $\begin{array}{l}\text { 1. Marriage rate, per } 1000 \text { people } \\
\text { 2. Divorce rate, per } 1000 \text { people } \\
\text { 3. Number of preschool educational organizations } \\
\text { 4. Number of culture and leisure organizations } \\
\text { 5. Number of organizations providing general education }\end{array}$ \\
\hline $\begin{array}{l}R_{3} \\
\text { Socioeconomic conditions }\end{array}$ & $\begin{array}{l}\text { 1. Retail trade turnover (except small business entrepreneurship) per resident, thous. rubles } \\
\text { 2. Number of unemployed registered by national employment service offices, persons } \\
\text { 3. Purchasing capacity of monthly average nominal gross wage (ratio to living wage, \%) } \\
\text { 4. Number of outpatient multiprofile and ambulatory walk-in organizations }\end{array}$ \\
\hline $\begin{array}{l}R_{4} \\
\text { Economy }\end{array}$ & $\begin{array}{l}\text { 1. Total volume of all food commodities sold within boundaries of municipal unit per one } \\
\text { resident, thous. rubles } \\
\text { 2. Agricultural products per one resident, thous. rubles } \\
\text { 3. Fixed investments per one resident, thous. rubles }\end{array}$ \\
\hline $\begin{array}{l}R_{5} \\
\text { Improvement and environment }\end{array}$ & $\begin{array}{l}\text { 1. Emission of pollutants into atmosphere by stationary sources, thous/t } \\
\text { 2. Total area of derelict and emergency-prone housing, thous. } \mathrm{m}^{2} \text {; number of residents in } \\
\text { derelict and emergency-prone housing } \\
\text { 3. Average area of housing per resident, } \mathrm{m}^{2}\end{array}$ \\
\hline
\end{tabular}

form blocks and lists of indicators representing various aspects of people's lives and socioeconomic development in municipalities (Table 1).

Table 1. List and blocks of indicators for measuring SOL and socioeconomic development of territory

The steps of the research include: (1) standardizing the values (relative to the means) in the entire set of indicators across the considered municipal districts (19) and urban districts (3); (2) computing the integral indicators in the interval from 0 to $1 ;(3)$ determining the interval scales for each of the blocks $R_{1}-R_{5}$; and (4) creating topical and summary (based on a synthetic measure of the level of socioeconomic development of municipalities in Belgorod oblast) schematic diagrams and making adequate inferences.

\section{RESULTS}

Demographic indicators $\boldsymbol{R}_{1}$. Figure 1 shows the differences in SOL revealed based on demographic indicators among municipal units of the region. Three levels of development dominate in the typology: high, upper middle, and middle. The lower middle and low categories include only one district each from the southeast and east of the oblast. Districts with an upper middle and middle SOL constitute the main body of the demographic block.
High SOL is characteristic of four municipalities: the city of Belgorod, Staryi Oskol urban district, and Yakovlevsky district (district center-Stroitel') - a suburb of the Belgorod agglomeration, as well as Alekseevka district at the periphery. All of these districts score high owing to towns and cities in their composition.

The demographic situation is a result of in-migration from the republics of the former Soviet Union in the 1990s and western migration drift of so-called "northerners" in the first decade of the 21st century. Migrants of both waves preferred to settle in cities, such as Staryi Oskol and Belgorod, and their suburbs, as well as in Gubkin and Alekseevka. From 2014 onwards, a similar situation arose in districts immediately adjacent to the borders of Ukraine; these districts welcomed refugees from Luhansk and Donetsk oblasts. The demographically positive echo of the migrations of the 1990 s and early 21 st century is evident to date.

The second, not least important reason contributing to the high level of demographic indicators in cities and suburbs is the attractiveness of the latter for people and businesses, causing centripetal migration flows from the periphery of the oblast. Large cities offer much greater opportunities for large incomes and selfrealization [15]. 


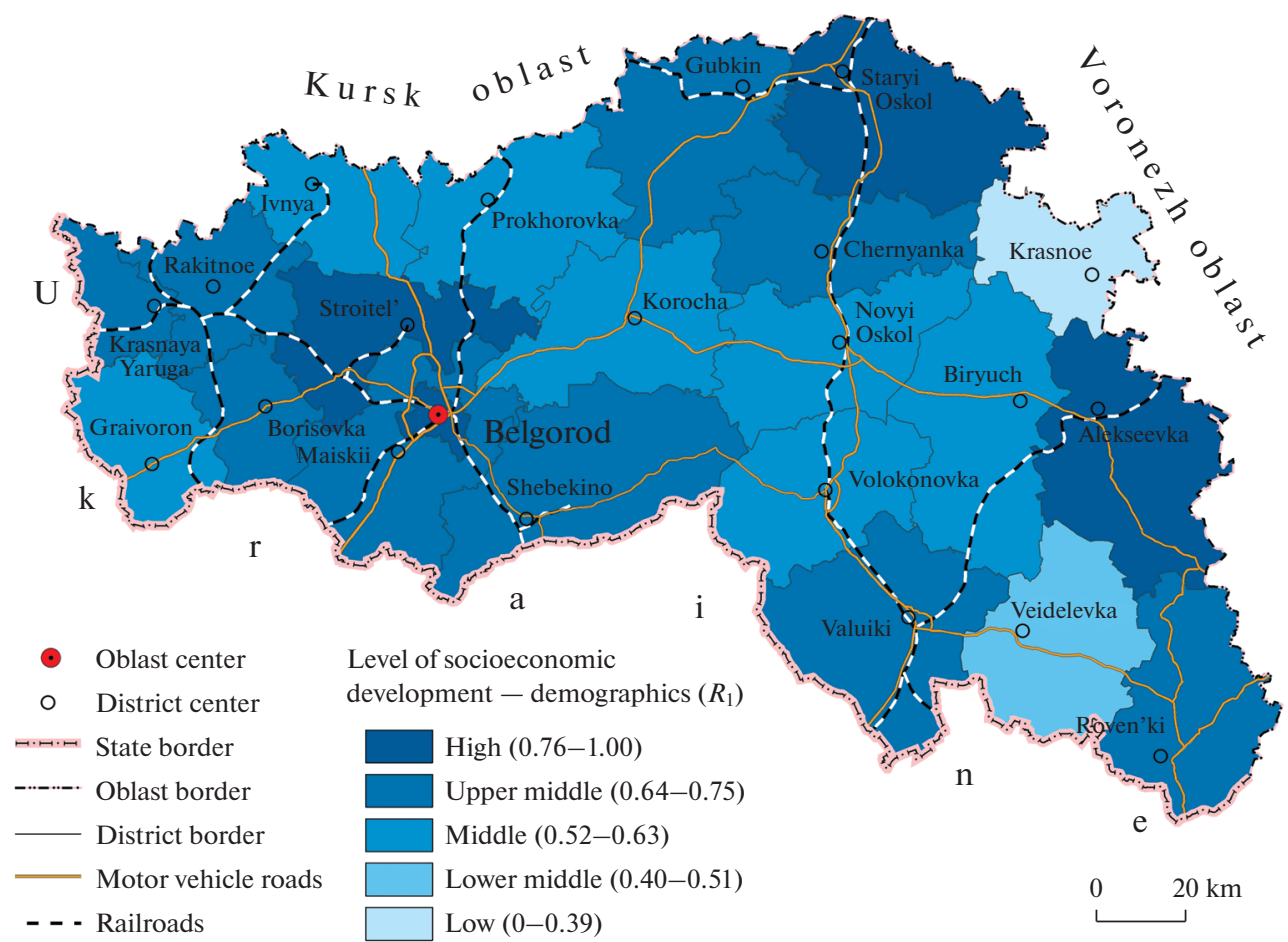

Fig. 1. Integral indicator of socioeconomic development of municipal units in Belgorod oblast based on Demographics block. Compiled from $[2,16]$.

Situation is particularly challenging in Krasnoe district (low-level type) at the oblast periphery as a result of the domination of agriculture as single industry, long-term negative net migration, and the highest mortality rate in the region $(23.5 \%$ ) [16] with a consequentially distorted age structure in the population and its ageing. Compared with the average for the oblast, the district features a low population density (14.1 people $/ \mathrm{km}^{2}$ ), although not critical for collective farming management, but leading to a scattered infrastructure [11], which projects onto the underperformance of social, socioeconomic, and economic blocks. A similar situation is observed in Veidelevka district (lower middle).

Social indicators $\boldsymbol{R}_{2}$. Social development of municipalities was to a certain extent influenced by demographic indicators, while other factors played a key role. Figure 2 shows the differences in SOL among municipal formations based on social indicators.

Belgorod is characterized by a high level of social indicators (0.78), which is quite predictable for a regional center with higher marriage rates than in other municipalities due to the young population structure, notwithstanding an overall downward trend in marriage registrations. The social block captures concentrations of preschool organizations and organizations providing general education, in Belgorod, specifically, $16 \%$ of kindergartens and $25 \%$ of their capacity in the region; as well as $9 \%$ of schools and $24 \%$ of schoolchildren [16]. The same factors determine the relatively stable situation (upper middle) in Staryi Oskol and Gubkin urban districts and Alekseevka.

A challenging situation is observed in 10 out of 22 municipal units in the region, where the social conditions are ranked as belonging to the lower middle and low categories due to the small number of registered marriages, high divorce rates, and insufficient provision of social institutions. The distorted age population structure is causing a decline in marriage rates due to migration outflow of youths from rural districts. In our opinion, the second reason is the spread of globalization processes, specifically, universalization of living standards and social norms and disruption of the customary mode of life. In the opinion of renowned experts, classically traditional family institution (golden age of legal marriage) is being replaced by free unions, while various forms of common law and cohabitation crowd out traditional marriage [9]. The number of registered marriages per 1000 persons declined from 8.7 to 6.1 (by $30 \%$ ) in Belgorod oblast during 2013-2016 [16].

However, the primary reason for low level of social living conditions in the population of Belgorod oblast districts is the recommendations originating from the federal center for "optimizing" local budgets in the education and culture sector and the resulting closure of schools with small classes (insufficient number of students) and clubs in rural localities. The network of 


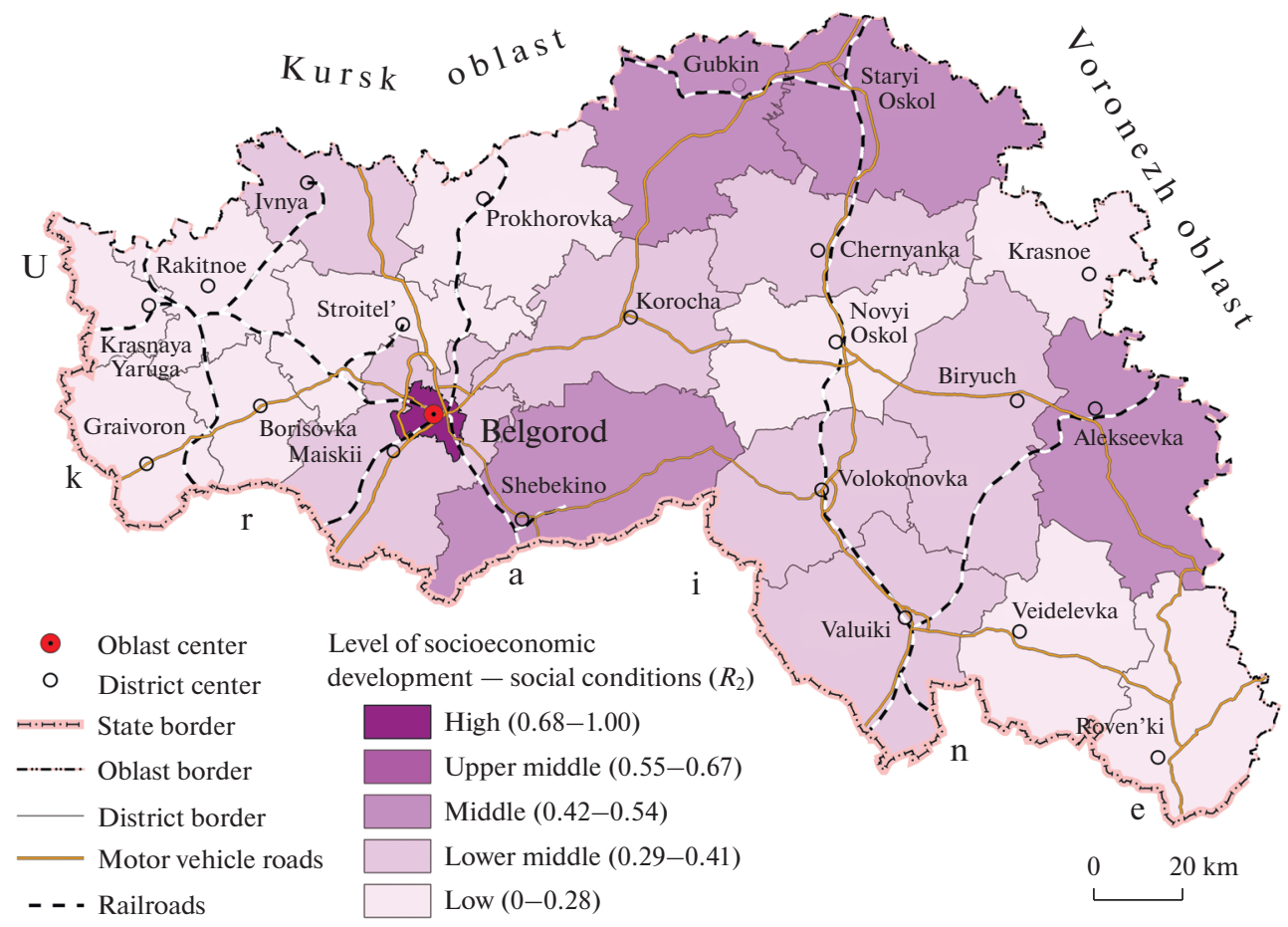

Fig. 2. Integral indicator of socioeconomic development of municipal units in Belgorod oblast based on Social conditions block. Compiled from [16].

social institutions has undergone radical quantitative changes in the early 21 st century. According to the Belgorod Statistics Office, there were 809 schools in operation in the 2001-2002 academic year and only 573 schools in 2015-2016. Their number dropped from 35 to 16 in Veidelevka district, from 22 to 10 in Krasnoe district, and from 31 to 22 in Prokhorovka district $[2,16]$. That kind of reforms will more than likely result in further "compression and shrinkage" [23, p. 167] of space, concentration and simultaneous reduction of inhabited economically active territories that multiple generations expended considerable effort to create.

Socioeconomic indicators $\boldsymbol{R}_{3}$. Adverse effects of poorly designed reforms have taken their toll on the performance indicators of socioeconomic block. The analysis identified a significant differentiation of SOL based on retail trade turnover, the number of unemployed between urban and rural residents, the purchasing capacity of the population, and access to medical care. The number of outpatient multiprofile and ambulatory walk-in clinics declined by a factor of 212 in some districts in 2012-2016 [16]. Figure 3 shows the intraregional differences in the level of socioeconomic development among municipal units of the oblast based on block $R_{3}$.

The cartogram indicates a high concentration in services and income of the population, in other words, "contraction to a locus" [23, p. 174], in or near the urban districts of Belgorod, Staryi Oskol, Gubkin, and
Alekseevka vs. a manifestation of symptoms of socioeconomic desertification across the southeastern and southern districts of the region.

The lowest level is characteristically displayed by Krasnoe district and districts that lie along the Ukrainian border (except those of Belgorod and Borisovka districts). Tightening border barriers are impacting retail trade turnover, new job creation, and, consequentially, the number of unemployed. This group of districts exhibits the lowest purchasing capacity, as well as average monthly nominal wages, due to localization of agroindustrial industries with low wages (except top managers). Job prestige somewhat affects the level of unemployment and occupation, especially among young people. The unattractiveness of agrarian sector for youths is governed by the low wages in agriculture, unfavorable work conditions, seasonality, and poorly developed social infrastructure. Our conclusions are further corroborated by international studies, which indicate that in recent decades, technological progress has led to the disparagement of physical work (manual labor), while "the global society altered traditional lifestyle regardless of our whereabouts" [6, p. 35].

SOL in the rural population $(33 \%$ of the oblast's population) was significantly affected by reorganizations in agriculture early in this century, specifically, the entry of federal and formation of regional agroholdings in Belgorod oblast that have been detrimental to household plots and farming. The adopted eco- 




Fig. 3. Integral indicator of socioeconomic development of municipal units in Belgorod oblast based on Socioeconomic conditions block.

Compiled from [16].

nomic policy resulted in a monopolistic position of agroholdings (agricultural organizations in Rosstat terminology or, in our opinion, national version of latifundia), which produced $87 \%$ of all agricultural product output and $98.7 \%$ of animal products in 2016 [2, p. 139] (GK Miratorg, OOO GK Agro-Belogor'e, OAO Belgorodskii bekon, etc.) and their establishment as a leading agricultural institution in the region, while individual peasant farms and farming enterprises have become uncompetitive. In 2014, agroholdings received $92 \%$ of all subsidies granted through the Ministry of Agriculture toward the development and support of agriculture in Russia [3], while small and medium-sized farms hardly received any government backing. Expectations that agroholdings will support the social rural sector are unreasonable, inasmuch as business will not become socially oriented until it has been legally imposed [26].

In Belgorod oblast, people traditionally raised pigs on their household plots for subsistence and sale. With the entry of agroholdings into animal husbandry, pork production on household plots was completely eliminated; household-owned pigs were destroyed due to African swine fever in 2013. Since then, large-scale agricultural enterprises have produced $100 \%$ of regional pork [2]. The idea of "household plots being oriented toward basic subsistence with a minor tradable component" $(14$, p. 7$)$ precisely describes the status quo in Belgorod oblast. This negatively affects population incomes, because as it is difficult to improve the SOL by engaging in household plot activities under the current conditions.

Accelerated technological progress, use of industrial and commercial production practices, and economies of scale lead to a predetermined reduction in the number of employed in agriculture and tension in local labor markets. In agriculture (it is inseparable from fishing and hunting in the Russian National Classifier of Types of Economic Activity (OKVED)), employment declined from $24 \%$ in 2000 to $18 \%$ in 2016 [2] and further triggered a rise in the real unemployment rate in the countryside due to limited diversification of the economy.

Suburban districts of Belgorod, Staryi Oskol, Gubkin, and Alekseevka gained an advantage from commuting and work opportunities in these urban centers. The employment of rural residents remains at unduly low rates on the eastern periphery. Estimates based on the ILO methodology revealed that the number of employed persons (excluding small businesses) ranges from $18 \%$ in Volokonovka district to $25 \%$ in Valuiki district (estimated by [16]), while the majority of the mobile and able-bodied population are pushed to leave for temporary work (otkhodnichestvo) or migrate from the countryside. These processes lead to the population ageing (retirees account for $36 \%$ in Volokon- 


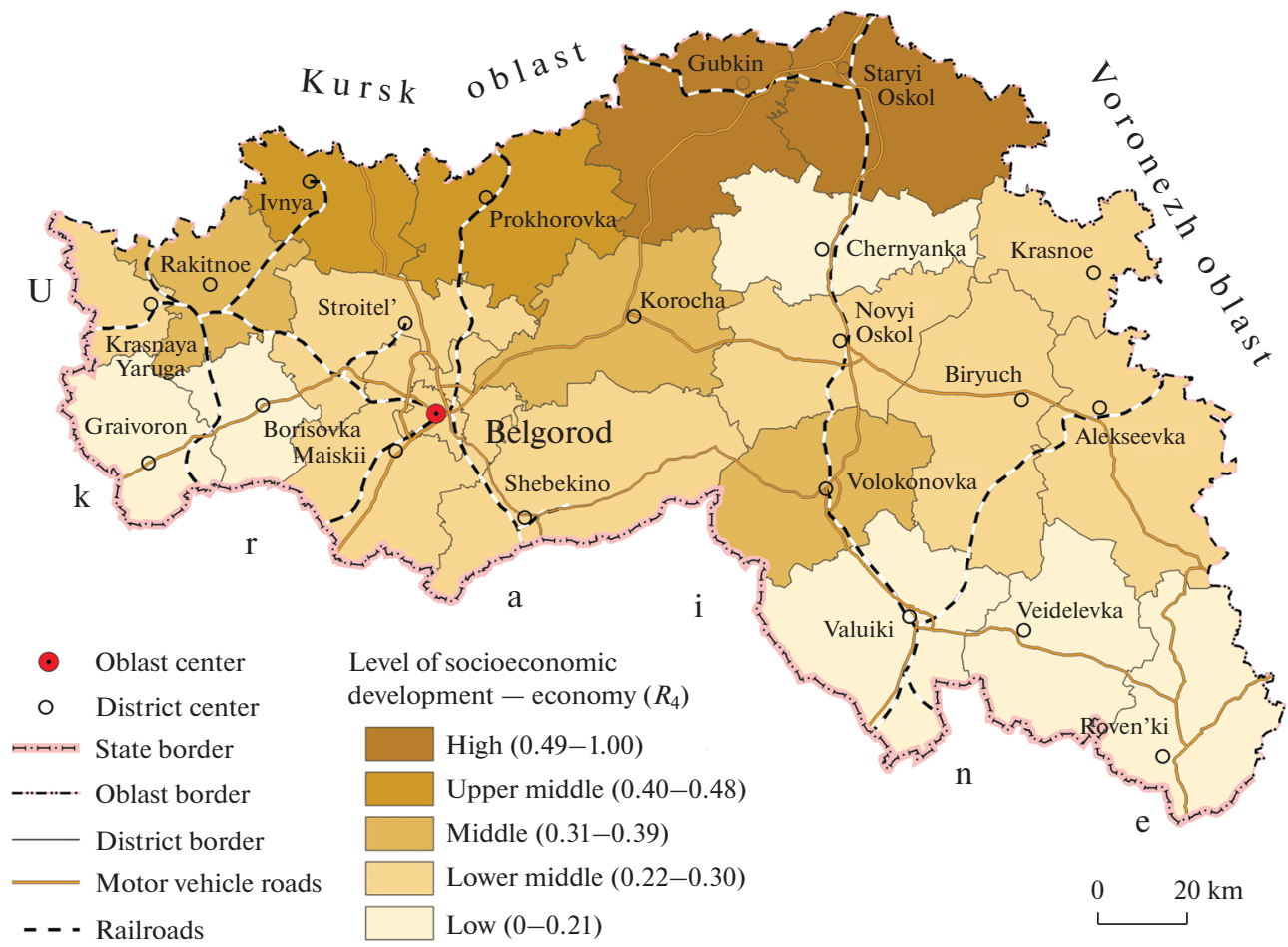

Fig. 4. Integral indicator of socioeconomic development of municipal units in Belgorod oblast based on Economy block. Compiled from [16].

ovka district and $34 \%$ of population in Valuiki district) and shortage of highly skilled professionals.

The differentiation of living conditions in the oblast population is equally manifested in the next block based on economic indicators.

Economy $\boldsymbol{R}_{\mathbf{4}}$. Figure 4 illustrates integral indicator of the socioeconomic status in the population of the municipal units in the economy block.

When analyzed, indicators revealed predictably high volume of realized food commodities in the regional center and centers of ferrous metallurgy (Staryi Oskol and Gubkin cities with their high-paid jobs) and the minimum volume at the oblast periphery as a representation of the purchasing capacity and income of the population. The expenditure pattern of the population demonstrates a high share $(33 \%$ of income) of food spending [2]. According to Engel's law, this points to poverty and scarcity of resources for medical treatment, education, leisure, and improvement of housing conditions. In 2015, monthly income did not exceed RUR 10000 in $14.1 \%$ of the regional population, i.e., below the subsistence level or on the edge of low-income level, and ranged from RUR 10000 to 15000 in $16.4 \%$ of the population [2]. A twoparent family with two children and average earnings of 25500 RUR [2] live on the brink of survival. In the fourth quarter of 2016 subsistence level was an estimated RUR 8099, while the minimum wage (MROT) was set at RUR 8694 in Belgorod oblast in 2016. The living environment of the Belgorod oblast population is a representation of the life of the population in Russia, "a rich country inhabited by the poor" [20, p. 33], featuring high-level polarization of wealth distribution and an income differentiation coefficient of 16 across the Russian Federation and 13 in Belgorod oblast [2]. Importantly, the coefficient did not take into account fringe groups of population $(7-10 \%)$ and super-rich Russians (5\%). In the opinion of experts, the actual gap between these population groups is greater than 30 -fold.

In terms of the agricultural production, Belgorod oblast has RUR 150000 for each of its residents due to the establishment of large-scale agricultural organizations (agroholdings) [2]. It ranks first among oblasts of the Central Chernozem economic area; however, this contributes little to the income level of the population.

The fixed investments are deeply differentiated and determined by investments in ferrous metallurgy (Gubkin and Staryi Oskol) and to the regional center (Belgorod), which account for $63 \%$. In addition to the urban districts, high-level investment indicators are specific to settlements with small populations where agroholdings have invested resources in the local agroindustrial complex (Ivnya, Korocha, and Prokhorovka districts).

Improvement and the environment $\boldsymbol{R}_{5}$. Figure 5 shows the integral indicator of the socioeconomic sta- 




Fig. 5. Integral indicator of socioeconomic development of municipal units in Belgorod oblast based on Improvement and environment block.

Compiled from [16].

tus of population in municipal units based on the improvement and the environment.

When analyzed, the official statistics showed a small share of derelict and disaster-prone housing and a largely favorable ecological situation. A detailed study of emissions into the atmosphere from stationary sources revealed the occurrence of microorganisms, organic matter, and odors [24] affecting quality of life in the zones adjacent to large animal husbandry complexes [24]. Changes in the agrarian structure of Belgorod oblast gave rise to impact from animal production and crop farming on natural components and complexes; in other words, the more successfully the regional agriculture develops, the higher the resource-ecology discordance [12] and the more significant the unfavorable alteration of the environment.

The urban districts of Staryi Oskol and Gubkin, as well as Yakovlevsky district, experience high industrial anthropogenic pressure as a result of iron ore mining and metallurgy. In Belgorod, the environment is polluted by enterprises of the construction industry, motor vehicles, etc. Our earlier research [25] pointed out that environmental diseases are likely to occur in the region's urban districts.

The indicator of the average housing area per regional resident considerably varies across municipalities of the oblast. The highest per capita housing supply is in Belgorod district: $49.3 \mathrm{~m}^{2} /$ person with a growth dynamics of $45 \%$ (since 2011) [2]. This results from suburbanization [28] in Belgorod agglomeration and the building and expansion of cottage settlements, to which the emerging regional middle class is moving.

Typology of municipal units based on the level of socioeconomic development. The synthetic measure (Fig. 6) reflects spatial differences in the level of socioeconomic development among municipal units. The present findings allow the inference of deep spatial polarization in the socioeconomic development of Belgorod oblast.

As should be expected from integral block analysis, a high level of economic development is exclusively specific to Belgorod as the oblast center, the urbandistrict of Staryi Oskol has been rated as upper middle, and nearly half of the regional municipalities are of the middle type. One-third of the districts fall into the lower middle category and about one-fifth are rated as low. The obtained result is a natural extension of the low level of indicators in the social block.

The short-term development trends in the social sphere are apparent. There are 291 abandoned rural localities and 19200 ha of formerly inhabited lands in the oblast [1]. Old failures in the restructuring of the rural population in the 1970s are likely to reoccur in the foreseeable future, as well as a repeat of the active migration of rural residents to cities in the 1980s, shortage of skilled manual labor, and the emergence of 




Fig. 6. Synthetic measure for socioeconomic development level of municipal units in Belgorod oblast.

more ghost villages. In the east of the oblast, $36 \%$ of localities are small in size and largely inhabited by the elderly. As they depart this life, "cracks and chips" in the once well-developed territory will spread even farther.

\section{CONCLUSIONS}

The complexity and ambivalence of the considered problem has necessitated the search for new approaches and techniques for measuring SOL differentiation when studying intraregional disproportions in socioeconomic development. The adopted integrated approach was able to measure the development level using demographic, social, socioeconomic, and economic indicators and living environment conditions and evaluate intraregional socioeconomic differences across Belgorod oblast.

Analysis of the integral SOL indicators designed and computed by the present authors revealed substantial gaps in living conditions among municipal units of Belgorod oblast. Persistently high and upper middle SOL levels are exclusively specific to the Belgorod, Staryi Oskol, and Gubkin urban districts and, to a lesser extent, to the town of Alekseevka. These populated areas are characterized by a favorable demographic situation, advanced social sphere, low unemployment rate, large fixed investments, and high levels of purchasing capacity and per capita housing supply, which make them equally attractive for people and businesses while stimulating rural-urban migration.

One-third of regional municipalities are ranked middle based on the SOL indicators. Nearly half the municipalities fall into the lower middle and low categories. The latter are rural areas where the low development level arises from the current situation in the social sphere and, ultimately, in socioeconomic development.

Contrasts in the life of people across municipal units have logically translated into intraregional disproportions between socioeconomic development levels. The advanced municipalities include Belgorod and its counterbalance in the regional settlement pattern system, Staryi Oskol (with Gubkin in the composition of a dual-core agglomeration). The point can be stretched to additionally include Alekseevka, which indicates the polycentric structure of the settlement pattern in Belgorod oblast.

The northern, southern areas, suburban zones of the Belgorod and Staryi Oskol-Gubkin agglomerations, and Alekseevka district (rural population) in the east all belong to municipal units with a middle level of socioeconomic development. Development trends can considerably differ among the middle district group depending on the directions of development of the cores of economic and civic life. The outlook for socioeconomic status is more favorable in the populations of suburban areas as a result of opportunities for 
employment and the buying of services in cities and towns.

Districts with low and lower middle development levels account for $45 \%$ of the districts of the region (central, southeast, and two districts in the west of the oblast), while somewhat contradicting the otherwise high score [19] of Belgorod oblast. However, it is not the regional rating that is important to people, but rather the modern level and status of living conditions in a particular district and locality. Preservation of the currently low level of socioeconomic development may accelerate selective migration while undermining the innovative development of extensive regional territories.

The process of constructing a model of the longterm planned development of rural areas taking into account differences in SOL can be done using a holistic approach to the spatial organization of society in depressed districts. It seems essential to define guidelines for the foreseeable future as applies to spheres, directions, and municipal units, followed by design of a model and programs to realize development with the subsequent introduction of these guidelines for all participants.

\section{FUNDING}

This study was supported by the Russian Foundation for Basic Research, project no. 17-03-00092/OGN.

\section{CONFLICT OF INTERESTS}

The authors declare that there are no conflicts of interests.

\section{REFERENCES}

1. Artishchev, V.E. and Goleusov, P.V., Post-inhabited geosystems of Belgorod oblast: physical-geographic characteristics and prospects for environmental rehabilitation, Usp. Sovrem. Estestvozn., 2016, no. 11-2, pp. 334-338.

2. Belgorodskaya oblast'v tsifrakh, 2017. Kratkii statisticheskii sbornik (Belgorod Oblast in Digits, 2017: Brief Statistical Handbook), Belgorod: Belgorodstat, 2017.

3. Babkin, K., Interview to information-analytical agency NakanuneRU. http://www.nakanune.ru/articles/111387/. Accessed February 8, 2016.

4. Bestuzhev-Lada, I.V., Analysis of standart and quality of living and lifestyle, in Sovremennye kontseptsii urovnya, kachestva i obraza zhizni (Modern Concepts of the Level, Quality, and Lifestyle), Moscow: Inst. Sotsiol. Issled., Akad. Nauk SSSR, 1978.

5. Brazhnikov, G.V., Differentiation of the standard and quality of of living of population in Russia, Narodonaselenie, 2006, no. 4, pp. 93-99.

6. Giddens, A., Runaway World: How Globalization is Reshaping Our Lives, London: Profile, 1999.

7. Gurdin, K., Capital truth, Argumenty Nedeli, 2017, no. 34 (576), Aug. 31.
8. Zherebin, V.M. and Romanov, A.N., Uroven' zhizni naseleniya (Standard of Living), Moscow: YuNITIDana, 2002.

9. Zakharov, S.V., Prospects of childbirth rate in Russia: the second demographic transition, Otechestvennye Zap., 2005, no. 3, pp. 124-140.

10. Zubarevich, N.V., Social development of Russian regions during transition period, Extended Abstract of Doctoral (Geogr.) Dissertation, Moscow: Moscow State Univ., 2003.

11. Karachurina, L.B. and Mkrtchyan, N.V., The role of migration in enhancing settlement pattern contrasts at the municipal level in Russia, Reg. Res. Russ., 2016, vol. 6 , no. 4, pp. 332-343.

12. Klyuev, N.N., Ecological and resource dissonance in agriculture of Russian regions, in Strategiya razvitiya prigranichnykh territorii: traditsii $i$ innovatsii (Development Strategy of Cross-Border Territories: Trends and Innovations), Kursk: Kursk. Gos. Univ., 2017, pp. 391397.

13. Levi, L. and Anderson, L., Psychosocial Stress Population, Environment, and Quality of Life, New York: Halsted Press, 1975.

14. Nefedova, T.G., Major trends for changes in the socioeconomic space of rural Russia, Reg. Res. Russ., 2012, vol. 2, no. 1, pp. 41-54.

15. Nefedova, T.G., Migration mobility of population and otkhodnichestvo in modern Russia, Reg. Res. Russ., 2015, vol. 5, no. 3, pp. 243-256.

16. Osnovnye pokazateli sotsial'no-ekonomicheskogo polozheniya munitsipal'nykh raionov $i$ gorodskikh okrugov Belgorodskoi oblasti (2012-2016 gg.) (General Indices of Socijeconomic Position of Municipal Districts and Urban Districts of Belgorod Oblast in 2012-2016), Belgorod: Belgorodstat, 2017.

17. Suggestions for the improvement of the Model set of social indicators for assessment of the standard of living of the population (based on the CIS Statistical Committee), Vopr. Stat., 2003, no. 7, pp. 36-38.

18. Rimashevskaya, N.M., Shevyakov, A.Yu., Kuznetsova, K.S., et al., Sistema ekonomiko-matematicheskikh modelei dlya analiza i prognoza urovnya zhizni (The System of Economic-Mathematical Models for Analysis and Forecast of the Standard of Living), Fedorenko, N.P. and Rimashevskaya, N.M., Eds., Moscow: Nauka, 1986.

19. Rating of the socioeconomic situation of the regions. http://www.credinform.ru/ru-Ru/herald/details/a9cee7f6184b. Accessed January 13, 2018.

20. Sdasyuk, G.V., N.N. Baranskiy as the founder of national economic geography: concept development, risk warning dor regional disintegration of Russia in 21st century (to the 135th anniversary of N.N. Baranskiy), Vestn. Assots. Ross. Geogr.-Obshchestvoved., 2016, no. 5, pp. 25-38.

21. Tikunov, V.S. and Chereshnya, O.Yu., Index of social development of the regions of Russian Federation, Izv. Ross. Akad. Nauk, Ser. Geogr., 2016, no. 1, pp. 19-24.

22. Tikunov, A.V., Use of geographical methods for evaluation of development of the countries and regions, Geogr. Prirod. Resur., 2005, no. 3, pp. 3-12.

23. Treivish, A.I., Compression of social geographical space: between reality and utopia, Materialy IX Sokra- 
ticheskikh chtenii "Problemy geograficheskoi real'nosti" (Proc. IX Socrates' Readings "Problems of Modern Geography”), Shuper, V.A., Ed., Moscow, 2012, pp. 166-190.

24. Chugunova, N.V., Polyakova, T.A., Delovaya, E.V., and Ignatenko, S.A., Modern socioeconomic and ecistic development of the suburb zone of an agglomeration, Probl. Reg. Ekol., 2012, no. 2, pp. 35-42.

25. Chugunova, N.V. and Sitnikova, O.O., The quality of the demographic potential of rural areas as a condition for the sustainable development of the region in a changing environmental situation (based on the materials of Belgorod oblast), Nauchn. Dialog. Estestv. Nau$k i, 2014$, no. 1 (25), pp. 140-153.
26. Chuikov, A., We need your land without people: Interview with V.L. Baburin, Argumenty Nedeli, 2017, no. 40 (582), Oct. 12.

27. Schneider, F. and Enste, D.H., Shadow economies: size, causes, and consequences, J. Econ. Liter., 2000, vol. 38, no. 1, pp. 77-114. http://corruption.rsuh.ru/ magazine/2/n2-18.shtml.

28. Chugunova, N.V., Polyakova, T.A., and Likhnevskaya, N.V., The development of the urban settlement system in Belgorod oblast, Geogr. Nat. Resour., 2013, vol. 34 , no. 1 , pp. 55-60.

Translated by E. Kuznetsova

SPELL: 1. OK 